\title{
MANAGEMENT OF SUPPLY CHAIN RISK IN CATTLE SLICE FATTENING AT PT. CATUR MITRA TARUMA
}

\author{
Aulia Rizky Elvandra*1, Mohamad Syamsul Maarif*, and Sukardi**) \\ *) School of Business, Bogor Agricultural University \\ SB IPB Building, Pajajaran Road, Bogor 16151 \\ **) Department of Agroindustrial Technology, Faculty of Agricultural Technology, Bogor Agricultural University \\ Building Fateta Floor 2, IPB Darmaga Campus, Bogor 16680
}

\begin{abstract}
PT Catur Mitra Taruma is one of the cattle fattening companies having a role as a source of beef cattle inventory for the beef processing industry. However, this company has the potential to experience a variety of supply chain risks that can hamper the company's business processes in carrying out its operational activities. The purpose of this study is to identify and analyze the risks that potentially appear in the process of supply chain beef cattle at PT. Catur Mitra Taruma, asses and evaluate identified risks, and formulate priority risk of mitigation and risk of chain action. The identification of supply chain risk was done using the dimensions of Supply Chain Operation Reference (SCOR). The method used in this study was the House of Risk method, an analysis that aims to identify and prioritize the source of risk for effective mitigation measures to minimize the potential risk and the source of existing risks. The identification results showed that the source process had the greatest risk of a total of 29 identified risk events in the company. In addition, there were 13 priority risk sources based on the ranking order of the priority risk index (ARP), rating of the total of 45 identified risk sources in the company. From the results of risk management analysis, there are recommendations of 10 priority risk mitigation actions that can be applied in PT. Catur Mitra Taruma in a potential supply chain risk prevention action in the company.
\end{abstract}

Keywords: supply chain, supply chain risk, risk management, House of Risk, cattle fattening business

\begin{abstract}
Abstrak: PT Catur Mitra Taruma sebagai salah perusahaan penggemukan sapi mempunyai peran sebagai sumber persediaan sapi potong untuk industri pengolahan daging sapi. Namun, perusahaan ini berpotensi mengalami berbagai risiko rantai pasok yang dapat menghambat proses bisnis perusahaan dalam menjalankan kegiatan operasionalnya. Tujuan penelitian ini adalah mengidentifikasi dan menganalisis risiko yang berpotensi muncul pada proses rantai pasok sapi potong di PT. Catur Mitra Taruma, menilai dan mengevaluasi risiko-risiko yang teridentifikasi, serta merumuskan tindakan mitigasi risiko rantai pasok prioritas. Identifikasi risiko rantai pasok dilakukan dengan menggunakan dimensi Supply Chain Operation Reference (SCOR). Metode yang digunakan dalam penelitian ini adalah metode House of Risk, yaitu analisis yang bertujuan untuk mengidentifikasi dan memprioritaskan sumber risiko untuk dilakukan tindakan mitigasi yang efektif untuk meminimalisir potensi risiko dan sumber risiko yang ada. Hasil identifikasi menunjukkan proses source memiliki risiko paling banyak dari total 29 kejadian risiko yang teridentifikasi di perusahaan. Selain itu, terdapat 13 sumber risiko prioritas berdasarkan urutan peringkat nilai indeks prioritas risiko (ARP) dari total 45 sumber risiko yang teridentifikasi di perusahaan. Dari hasil analisis penanganan risiko, terdapat rekomendasi 10 tindakan mitigasi risiko prioritas yang dapat diterapkan di PT. Catur Mitra Taruma dalam tindakan pencegahan risiko rantai pasok yang berpotensi muncul di perusahaan.
\end{abstract}

Kata kunci: rantai pasok, risiko rantai pasok, manajemen risiko, house of risk, usaha penggemukan sapi

\footnotetext{
${ }^{1}$ Corresponding author:

Email: rizkyelvandra@gmail.com
} 


\section{INTRODUCTION}

Based on the data from the Central Bureau of Statistics/ BPS (2016), the growth of beef consumption in Indonesia had a positive trend from 2010 to 2015 with an average growth rate increase of $22.26 \%$ per year. However, the increase in consumption of beef was not in line with the condition of beef production in Indonesia. This was shown from the data taken from BPS (2016), in which the national beef production trend had decreased in the range of 2012-2015. Based on these data, the average annual growth in beef production in Indonesia in 20122015 had a value of $-0.41 \%$.

Slow growth in beef production, accompanied by increased consumption of beef, can lead to supply shortages in the beef processing industry that can not meet the consumers' need for beef. To handle this problem, the beef processing industry is required to increase production by increasing the supply of raw material of beef cattle. Beef cattle farming can play a role in contributing the supply of beef cattle to the beef processing industry. An-nisa et al. (2015) suggested in her research that business activities of beef cattle are often confronted by various risks, one example is productivity. Therefore, every beef cattle farm should be able to maintain its supply chain especially in handling supply chain risk.

Supply chain risks are all risks from the flow of information, materials, and products or disruptions caused by the complexity of corporate relationships with external parties (Pujawan \& Geraldin, 2009). To reduce the disturbance, good supply chain risk management is required. According to Chen et al. (2013), supply chain risk management is the management of the supply chain by collaborating between the parties concerned to deal with and minimize the discomfort associated with logistics activities in a supply chain.

The cattle fattening business can be one of the cattle breeding businesses that can handle some of the problems mentioned above. Cattle fattening business is an effort to maintain adult cattle in a lean condition to increase their weight through the enlargement of meat in a relatively short time (Firdausi et al. 2012). PT. Catur Mitra Taruma is one of the cattle fattening companies and is incorporated in the association of Indonesian Cattle Business Farmers Association (GAPUSPINDO), which was formerly known as the
Association of Indonesian Feedlot Entrepreneurs (APFINDO) (Pujiastuti, 2015). The acquisition of beef cattle in this company comes from imports using some imported cattles that have a superior genetic base strong physically, and resistant to disease.

At the end of 2016, the government adopted a new regulation on cattle import quotas. The management of PT. Catur Mitra Taruma felt that the regulation of cattle import quota from the government that often underwent changes could cause uncertainty, so this frequent change could affect the supply chain of the company. In more details, the imposition of import quotas can affect the procurement of imported beef cattle at PT Catur Mitra Taruma. Based on Permentan No.16 of 2016 on Ruminants Large Livestock Import into the Republic of Indonesia, cattle importers were required to bring one cattle for every five cattle they imported. Obligation to procure this brood stock can affect the operational activities of PT. Catur Mitra Taruma which does not cover breeding activities. This encourages companies to make sudden internal changes such as changes in cage infrastructure, operational planning, maintenance management, and so on.

As a cattle fattening company, PT. Citra Mitra Taruma also has the potential to face other supply chain risks, such as the presence of some sick cows and cows that do not reach the desired weight target during the fattening process at any given time. PT. Citra Mitra Taruma does not yet have a structured supply chain of risk management system to identify and address some of the possible supply chain risks in the company. This can affect the competitiveness of companies in the cattle fattening industry. By conducting a structured risk management, the company can maintain its business continuity. Therefore, research on risk analysis and risk management measures of beef cattle supply chain in PT. Catur Mitra Taruma was performed to enable companies to prevent the risks that affected the company's business processes. Improper business processes resulting from supply chain risks can cause breakdowns or company setbacks (Geraldin et al. 2007).

This study aims to identify and analyze potential risks or disruptions in the supply chain process of beef cattle at PT. Catur Mitra Taruma, assess and evaluate the risks identified at PT. Catur Mitra Taruma, and formulate priority risk of mitigation risk of chain action at PT. Catur Mitra Taruma. This research will use case study 
approach with House of Risk (HOR) method. The scope of the research is limited to internal activities and chain companies.

The research by Dewi et al. (2015) examines risk management on new product developments for the hijab industry, also using the HOR method with FMEA integration. The difference between the research there and the research at PT. Catur Mitra Taruma lies in the number of research objects and scope coverage. The risk management research on the hijab industry examines more than one company relating to the hijab industry supply chain. In addition, the scope under study is not only in the supply chain but also product, finance, and enterprise management characteristics.

There are other studies using the FMEA method as well, but not integrated with the HOR method. As in the research by Aini et al. (2014) and Risqiyah \& Santoso (2017) using FMEA method. In Aini et al. (2014), the FMEA method is integrated with the Analytical Network Process (ANP) method by examining the supply chain of cocoa commodities while Risqiyah \& Santoso (2017) examined the agricultural supply chain.

\section{METHODS}

Data in this research consist of primary data and secondary data. Primary data were collected by observation, questionnaire, and direct interview to survey respondents. Secondary data were obtained through literature studies, corporate documents, scientific journals, and other publications. The study was conducted in March-July 2017 at the company's cage center located in the Cariu area.

The data were collected by purposive sampling technique, i.e. sampling based on expertise on the subject studied. Criteria of respondents needed in this study consist of internal parties of PT. Catur Mitra Taruma that understood and were involved in the supply chain process of the company's products. A total of 7 respondents consisted of Director of Operations and Commerce, Finance and Administration Director, Senior Veterinary Maintenance Manager, Senior Facility Maintenance Manager, Animal Maintenance Manager, Nutrition Manager, and Animal Health Supervisor.
The research stage can be seen from the framework of thought presented in Figure 1. For data analysis, the method used is House of Risk (HOR) method, that is, integration of FMEA (Failure Modes and Effects of Analysis) model and QFD model (Quality Function Deployment). Application of HOR analysis consists of two stages, namely risk identification with HOR 1 method and risk management with HOR 2 method.

The process of analysis of HOR 1 has several stages as follows:

1. Identification of potential risk events (Ei) occurring and causing disruption to each supply chain process. This risk event can be identified based on each supply chain activity on the SCOR concept (plan, source, make, deliver, and return).

2. Determination of the level of impact/severity ( $\mathrm{Si}$ ) of each identified risk event. This level of impact illustrates the extent of the disruption caused by any risk occurrence to the supply chain. The scale used to determine the impact level of risk ranges from 1-10 in which 10 shows the greatest impact.

3. Identification of risk sources $(\mathrm{Aj})$ i.e any factor that can lead to occurrence of identified risk events.

4. Assessment of probability/occurrence (Oj) level of each risk source on a scale of 1-10 where 1 means that almost never occurs and a value of 10 means that the risk source assessed is frequent.

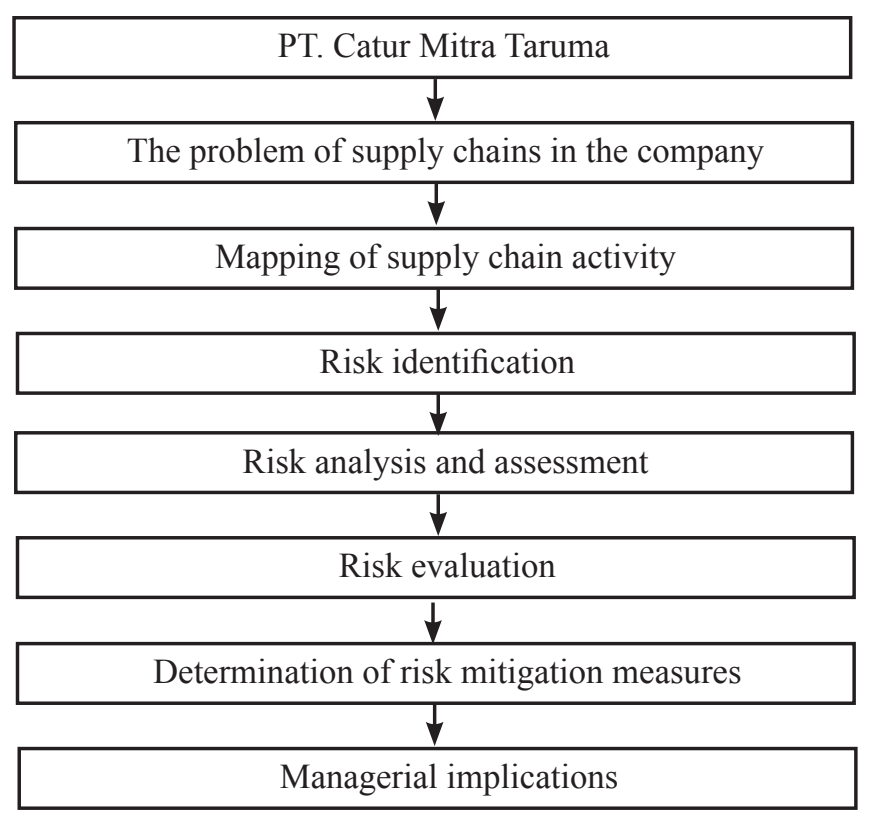

Figure 1. Research framework 
5. Measurement of correlation/correlation (Rij) between an event of risk with the source of risk. This correlation indicates a source of risk that may lead to an event of risk. The correlation scale ranges from $(0,1,3,9)$ where a value of 0 (or no value at all) indicates no full correlation, value 1 denotes a small correlation, value 3 represents a moderate correlation, and a value of 9 represents a high correlation.

6. Calculation of Aggregate Risk Potential (ARPj) value determined as a result of the probability of occurrence of the source of the risk and the set of causal impacts of each risk event caused by a risk source such as the following equation:

$$
\mathrm{ARPj}=\mathrm{Oj} \sum \mathrm{Si} \mathrm{Rij}
$$

In which: ARPj (the value of risk priority index); $\mathrm{Oj}$ (the value of occurence from each risk source); $\mathrm{Si}$ (the value of severity from each risk occurance); Rij (the value of correlation between risk occurance and risk source).

7. Sorting of risk sources based on the order of high ARP values to determine the priority of the source of risk to be selected.

The steps in the HOR 2 analysis are as follows:

1. Selection of risk source priority based on highest to lowest ARP value from HOR 1 analysis using pareto diagram. High priority risk sources will be used as inputs from HOR 2 analysis.

2. Identification of consideration of relevant risk mitigation measures (PAk) for the prevention of risk sources (Aj). A risk mitigation action may apply to one or more sources of risk.

3. Determination of correlation (Ejk) between risk sources and risk mitigation measures on a scale $(0$, $1,3,9)$ which showed no correlation, low, moderate, and high correlation. The relationship of this correlation can be used as a level of effectiveness in reducing the emergence of risk sources from risk mitigation measures.

4. Calculation of the total effectiveness of mitigation measures (TEk) by equation: $\mathrm{TEk}=\mathrm{ARPj}$ Ejk

5. Determining the approximate level of difficulty in the application of mitigation actions (Dk) which can be demonstrated by Likert scale (1-5).

6. Calculation of total effectiveness of mitigation action implementation (ETDk) by equation:

$\mathrm{ETDk}=\mathrm{TEk} / \mathrm{Dk}$
7. Sequencing the ranking of risk mitigation measures based on the order of high ETDK values with the roof component of HOR 2 model to determine priority mitigation actions.

\section{RESULTS}

\section{Identification and Risk Assessment}

Risks identified and assessed consist of risk events and risk agents. Identification and assessment of supply chain risk in PT. Catur Mitra Taruma conducted by observation and interview in the form of questionnaires to the relevant internal parties and understand the supply chain in the company.

The risk occurrences found are the types of operational risks that are divided into five dimensions of SCOR theory consisting of process plan, source, procurement, deliver, and return. In detail, risk is identified by the subprocesses of processes in the SCOR theory dimension. In addition, the level of impact (severity) of identified risk events is based on the extent of the disturbance caused by the risk events that may impact the company with a scale of $1-10$ values where the value of 10 shows the greatest impact. Risk incidence in PT. Catur Mitra Taruma can be seen in Table 1. Risks are not only the risks that have been or often happened in PT. Catur Mitra Taruma, but there are risks that may occur in the future.

Out of the 29 risk events in PT. Catur Mitra Taruma, there are 8 risk events in the process plan, 9 risk events in the source process, 7 risk events in the making process, 4 risk events in the delivery process, and 1 risk event in the return process. From the description, it can be said that the source process has the highest number of risk events. This is because the process of source activity has a greater risk, because this process chain is the longest compared to other process chains. Ulfah et al. (2016) held a study identifying the risk of refined sugar supply chain that shows that the making process of refined sugar supply chain has the highest number of risk events because the activity in the making process of the refined sugar supply chain has the greatest frequency than any other process. 
Table 1. Risk occurance at PT. Catur Mitra Taruma

\begin{tabular}{|c|c|c|c|c|}
\hline Process & Sub-process & Risk Occurance & Impact & Code \\
\hline \multirow[t]{8}{*}{ Plan } & \multirow[t]{4}{*}{ Demand Forecast } & There was an uncertainty of production forecast & 4 & E1 \\
\hline & & $\begin{array}{l}\text { There was a problem in which the selling target was not met as } \\
\text { planned }\end{array}$ & 4 & E2 \\
\hline & & There was a problem in which market demand was not met & 3 & E3 \\
\hline & & There was a problem of deman uncertainty from customer & 4 & E4 \\
\hline & \multirow[t]{2}{*}{ Production Plan } & There was a sudden change in production plan & 5 & E5 \\
\hline & & $\begin{array}{l}\text { There was a plan error in the production equipment/ machine } \\
\text { maintenance }\end{array}$ & 4 & E6 \\
\hline & Capacity Plan & The use of capacity was sometimes not optimal & 5 & E7 \\
\hline & $\begin{array}{l}\text { The appropriation of } \\
\text { supply with budget } \\
\text { planning. }\end{array}$ & There was a problem in the improper budget planning & 3 & E8 \\
\hline \multirow[t]{9}{*}{ Source } & The availability control & $\begin{array}{l}\text { There was an uncertainty between feed availability or the } \\
\text { available cows recorded }\end{array}$ & 6 & E9 \\
\hline & $\begin{array}{l}\text { The schedule of } \\
\text { delivery from the } \\
\text { supplier. }\end{array}$ & $\begin{array}{l}\text { There was a problem of cattle data delay from the supplier } \\
\text { (exporter) }\end{array}$ & 3 & $\mathrm{E} 10$ \\
\hline & \multirow{2}{*}{$\begin{array}{l}\text { The acquisition of } \\
\text { material delivery from } \\
\text { the supplier. }\end{array}$} & There was a problem of unhealthy cows from supplier & 2 & E11 \\
\hline & & $\begin{array}{l}\text { There was a problem in the process procedure of inproper cattle } \\
\text { checking }\end{array}$ & 4 & $\mathrm{E} 12$ \\
\hline & \multirow{2}{*}{$\begin{array}{l}\text { The process of } \\
\text { material sent by the } \\
\text { supplier }\end{array}$} & $\begin{array}{l}\text { There was a proble of delay in the process of playment between } \\
\text { the company and the supplier }\end{array}$ & 5 & E13 \\
\hline & & $\begin{array}{l}\text { There was an additional cost (procurement) beyond the } \\
\text { expectation }\end{array}$ & 5 & E14 \\
\hline & Supplier selection & There was a mistake in supplier selection & 3 & E15 \\
\hline & $\begin{array}{l}\text { Supplier performance } \\
\text { evaluation }\end{array}$ & $\begin{array}{l}\text { There was a mistake in the supplier performance evaluation which } \\
\text { was not done }\end{array}$ & 2 & E16 \\
\hline & $\begin{array}{l}\text { Process of } \\
\text { procurement (import) }\end{array}$ & $\begin{array}{l}\text { There was a mistake in processing the document related to the } \\
\text { procurement process }\end{array}$ & 4 & E17 \\
\hline \multirow[t]{7}{*}{ Make } & \multirow{6}{*}{$\begin{array}{l}\text { Execution and } \\
\text { operational control }\end{array}$} & There was an unhealthy condition of cow & 5 & E18 \\
\hline & & There was a feed availability which could not be used & 2 & E19 \\
\hline & & $\begin{array}{l}\text { There was feed quality which was not in accordance with the } \\
\text { standard }\end{array}$ & 5 & E20 \\
\hline & & $\begin{array}{l}\text { There was a problem in the fulfillment of cattle barn capacity } \\
\text { which was not maximal }\end{array}$ & 4 & $\mathrm{E} 21$ \\
\hline & & $\begin{array}{l}\text { The additional cost in the production activity which was beyond } \\
\text { the expectation }\end{array}$ & 3 & E22 \\
\hline & & $\begin{array}{l}\text { There was an engine damage whihc related to the operational } \\
\text { activity }\end{array}$ & 5 & E23 \\
\hline & $\begin{array}{l}\text { Perform a maintenance } \\
\text { process }\end{array}$ & The decrease of cattle quality during the process & 2 & E24 \\
\hline \multirow[t]{4}{*}{ Delivery } & $\begin{array}{l}\text { Delivery channel } \\
\text { Selection }\end{array}$ & There was a cattle transportation error & 3 & E25 \\
\hline & \multirow{3}{*}{$\begin{array}{l}\text { Delivery process to } \\
\text { customer }\end{array}$} & There was a problem of unhealthy cattle condition during the trip & 6 & E26 \\
\hline & & The delay of product delivery to the customer & 6 & $\mathrm{E} 27$ \\
\hline & & Additional cost (delivery) beyond the expectation & 4 & E28 \\
\hline Return & $\begin{array}{l}\text { The cattle return from } \\
\text { the customer }\end{array}$ & There were customer complaints & 6 & E29 \\
\hline
\end{tabular}


Based on the value of the risk impact, there are four risk events that have the highest impact value of 6 . The risk consists of nonconformity problems between recorded and available feed stocks (E9), there are problems with unhealthy cattle conditions during the trip (E26), delay of delivery of product to customer (E27), and customer complaint (E29).

The occurrence of a mismatch between recorded and available inventory can lead to disruption of the production process/operations and delivery processes to customers as disclosed in Ulfah et al. (2016). The study also said that the delay in the company's product delivery process can lead to decreased customer satisfaction. This is the reason for the high value of the impact of risk on the incidence of risk of nonconformity between the inventory (stock) of feed or cattle listed and available (E9) and the delay in delivery of the product to the customer (E27).

The cause of the high value of the impact of risk on the occurrence of the risk of the problem on unhealthy cattle condition during the trip (E26) causes this risk decrease in the quality of cattle and death in cattle; therefore, this affected customer satisfaction. Ahmad RZ (2008) in his study said that the disease in livestock resulted in not achieved optimal productivity and can cause death in the livestock itself. While the value of the impact on customer complaint risk (E29) is high because these risks can affect the productivity of the company. As stated by Hartini (2012) in her research, this reveals that the lower the level of complaints from customers, the higher the performance of the company.

In addition to risk events, risk sources are also identified and assessed at this stage. Sources of risk are factors that can lead to occurrence of identified risk events. Identification of these sources of risk can be helpful in determining the risk management measures that can be taken to prevent these sources of risk from occurring in the future (Handayani, 2014). Results of identification of risk sources at PT. Catur Mitra Taruma with an occurrence value can be seen in Table 2. The frequency value represents the probability of occurrence of the occurrence of the identified risk source. The frequency value scale ranges from $1-10$ where the value of 1 states that this almost never occurs and a value of 10 means that this often happens (Chen, 2007).
According to Table 2, there are 45 possible risk sources at PT. Catur Mitra Taruma. Out of the 45 sources of these risks, the source of currency exchange rate risk (A22) and census import quotas from the frequently changing government (A23) has the highest frequency value with a value of 10 .

Both risks can be categorized as external risk because these risks come from outside the company's internal environment. According to Pujawan \& Geraldin (2009), most of the causes of supply chain risk are related activities with outsiders. This statement supports the high value of risk frequency in both sources of risk.

\section{Evaluation dan Determination of Priority Risk Source}

In the risk handling, not all sources of risk can be mitigated. This is due to several factors such as costs in the handling process or one source of risk having too little impact. Therefore, it is important to determine priority risk sources to facilitate in the design of risk mitigation action.

The priority risk source can be determined by sequencing the Aggregate Risk Potential (ARP) value or the risk priority index value. To calculate the ARP value, three parameters are severity, occurrence, and correlation (the relationship between risk events). The correlation value between risk events and risk sources is obtained from the interviews of respondents. The correlation value scale ranges from $(0,1,3,9)$ where a value of 0 (or no value at all) indicates no full correlation, value 1 denotes a small correlation, value 3 represents a moderate correlation, and a value of 9 represents a high correlation. After getting the value of severity, occurrence, and correlation, ARP value of a risk source can be obtained from the multiplication of the three parameters according to the ARP calculation formula. The ARP value is sorted to find out the order of priority risk sources.

Determining the priority risk source of the ARP value from each risk source can be determined by the Pareto chart. Pareto's legal application of risk means that $80 \%$ of the company's losses is due to a crucial $20 \%$ risk. By focusing on the $20 \%$ of crucial risks, the impact of corporate risk by $80 \%$ can be overcome (Anggrahini et al. 2015). Priority Risk Source can be seen in Table 3. 


\begin{tabular}{|c|c|c|}
\hline Code & Risk source & Frequency \\
\hline A1 & The system of less standard demand plan & 4 \\
\hline $\mathrm{A} 2$ & There was no work procedure of sales & 5 \\
\hline A3 & The cattle quality decreased after the fattening process & 2 \\
\hline A4 & The price of cattle selling is not competing & 4 \\
\hline A5 & There was new competitors & 5 \\
\hline A6 & Lack of promotion & 3 \\
\hline A7 & Seasonal factor affecting the cattle selling & 8 \\
\hline A8 & The decrease of customer's purchasing power. & 5 \\
\hline A9 & The increase of imported cattle price & 7 \\
\hline A10 & Natural factor/environtment affecting the transportation & 3 \\
\hline A11 & Natural factor/environement affecting the cattle maintenance & 6 \\
\hline A12 & There was a damage engine/equipment relating to the business process & 7 \\
\hline A13 & Suddent demand from the customer/slaughterhouse & 5 \\
\hline A14 & Lack of communication and information among workers & 2 \\
\hline A15 & Mistake of data input & 3 \\
\hline A16 & The damage of IT system & 5 \\
\hline A17 & Less inappropriate procurement plan & 3 \\
\hline A18 & Bad cattle monitoring & 2 \\
\hline A19 & Performance factor of machine equipment relating to the operational process & 3 \\
\hline A20 & Lack of worker's concern to support the company's activity & 3 \\
\hline A21 & Lack of machine maintenance management & 3 \\
\hline A22 & The change of currency rates & 10 \\
\hline A23 & The imported cattle quata from the government which often happened & 10 \\
\hline A24 & The increase of wage price & 3 \\
\hline A25 & Procedure of disorganized delivery & 2 \\
\hline A26 & Bad process of cattle expenditure in the port & 2 \\
\hline A27 & The delay of cattle delivery process from the supplier & 4 \\
\hline A28 & Mistake happening in the process of cattle checking/material from the supplier & 3 \\
\hline A29 & Incomplete requirement of administration from the supplier was not & 1 \\
\hline A 30 & There was no supplier criteria determination & 2 \\
\hline A31 & The unprepared supplier to supply the cattle/raw material & 1 \\
\hline A32 & Limited human resources & 2 \\
\hline A33 & Inaccuracy of human resources & 2 \\
\hline A34 & Lack of cage cleanliness & 2 \\
\hline A35 & Bad quality of feed & 1 \\
\hline A36 & The plan of inappropriate operational process & 2 \\
\hline A 37 & The fluctuation of customer's demand/slaughterhouse & 5 \\
\hline A38 & There was no fattening process procedure & 1 \\
\hline A39 & There was no procedure of clear quality control & 2 \\
\hline A40 & Disturbed electricity supply & 5 \\
\hline A41 & Lack of transportation equipment availability & 2 \\
\hline A42 & The delay of cattle delivery to the customer/slaughterhouse & 3 \\
\hline A43 & Incompleteness of information from customer/slaughterhouse & 2 \\
\hline A44 & There was a disruption/ accident during the process of transportation & 2 \\
\hline A45 & Lack of communication and information in the procurement division & 2 \\
\hline
\end{tabular}


Table 3. Determining the source of priority risk

\begin{tabular}{cccccc}
\hline Priority & Code & ARP & Total CumARP & \% Total CumARP & Classification \\
\hline 1 & A23 & 2.090 & 2.090 & 10.33 & \\
2 & A11 & 1.896 & 3.986 & 19.70 & \\
3 & A7 & 1.824 & 5.810 & 28.71 & \\
4 & A12 & 1.736 & 7.546 & 37.29 & \\
5 & A9 & 1.624 & 9.170 & 45.31 & \\
6 & A16 & 1.236 & 10.406 & 51.42 & \\
7 & A20 & 978 & 11.384 & 56.25 & Priority \\
8 & A13 & 875 & 12.259 & 60.57 & \\
9 & A37 & 860 & 13.119 & 64.82 & \\
10 & A10 & 858 & 13.977 & 69.06 & \\
11 & A19 & 810 & 14.787 & 73.07 & \\
12 & A4 & 760 & 15.547 & 76.82 & \\
13 & A44 & 672 & 16.219 & 80.14 & \\
\hline
\end{tabular}

According to Table 3, there are 13 sources of risk that, when handled, $>80 \%$ of the risk impacts from all 45 risk sources can be addressed as well. This is because the 13 sources cover $80 \%$ of the cumulative total of ARP. Therefore, companies should pay more attention to the 13 priority risk sources by prioritizing the risk sources for mitigation actions. By handling these 13 sources of risk, it is hoped that the rest of the other risk sources can be automatically resolved.

\section{Risk Management Analysis}

The initial stage in conducting risk management analysis is to design and formulate mitigation actions that can minimize or eliminate the emergence of existing sources of risk. The formulation of risk mitigation actions is done by direct author observation and in-depth interviews on the respondents.

After formulating mitigation actions from risk sources, the next step is to calculate the Total Effectiveness (TEk) value of each mitigation action. The TEk scores calculated from each mitigation measure do not illustrate how well these precautions can effectively deal with some of the risks. Therefore, it is necessary to calculate the Effectiveness to Difficulty Ratio (ETDk) value of each mitigation action. This ETDK value can illustrate the level of effectiveness of mitigation actions can be realized to deal with risk. To calculate the ETDk value, a TEk value and the Degree of Difficulty (Dk) value of each risk mitigation action are required. DK value describes how difficult risk mitigation measures applied to the company. ETDK values are needed to determine the priority sequence of mitigation actions by sorting those values from each mitigation action from highest to lowest.

The determination of priority action is carried out to find out alternative risk mitigation measures that can be implemented. This is because not all mitigation measures can be implemented given the limited cost, human resources, and some other aspects of the company. The establishment of risk mitigation measures using the roof component method of the House of risk 2 model where mitigation actions are grouped according to the level of relationships among robust risk mitigation actions so that unnecessary mitigation of risk mitigation is possible. As in Ulfah (2016) research, strongly linked risk mitigation measures will be classified into one group where priority risk mitigation actions are determined on the basis of the highest ETDk values in a particular group based on the priority order already in place. The level of relationship between robust risk mitigation measures is determined by the author's observation. Detailed data on the determination of priority risk mitigation measures can be seen in Table 4 .

The eight actions that have the highest ETDK value in each group are priority risk mitigation actions. In the act of improving the quality of cattle fattening at the time of high market (PA8) and periodic backing up of corporate data and documents (PA16) has no strong relationship with other risk mitigation measures so that these actions automatically include risk mitigation priority measurement. 
Table 4. Action Determination of priority risk mitigation

\begin{tabular}{clrc}
\hline Code & Mitigation Action & ETDk & Mitigation Action applied \\
\hline PA9 & Plan and perform the maintenance/ routine facility monitoring & 34.038 & PA9 \\
PA10 & Shutdown/maintenance every year & 22.914 & \\
PA12 & Training the staff concerning the maintenance & 3.009 & \\
PA4 & Implement the Cattle Business Insurance (AUTS) to the business process & 15.417 & PA5 \\
PA5 & Maximize the feed administration consisting vitamin the cattle's stamina & 17.064 & \\
PA6 & Perform marketing research periodically & 7.752 & PA6 \\
PA7 & Form marketing team intensively & 5.814 & \\
PA11 & Perform performance evaluation and routine correction action & 15.432 & PA11 \\
PA17 & Develop reward system and pusnishment to the staff & 4.401 & \\
PA18 & Develop staff monitoring based on the drive of working motivation to the & 2.934 & \\
& staff & & \\
PA23 & Socialization of PIC for transportation/ delivery telp number & 4.590 & PA24 \\
PA24 & Improve the coordination of PIC for transportation/ delivery & 13.770 & \\
PA2 & Perform diversification of cattle procurement source based on the local & 10.443 & PA2 \\
& cattle & & \\
PA13 & Perform imported cattle procurement efficiently and effectively & 7.308 & \\
PA14 & Evaluation of supply routinely & 2.436 & \\
PA15 & Find the procurement source from other suppliers & 2.436 & \\
PA1 & Change the business concept based on the cattle volume becoming perfor- & 6.270 & PA3 \\
& mance-based cattle after post harvest & & \\
PA3 & Increase the import realization by increasing the cage capacity & 9.405 & PA8 \\
PA19 & Contract with the customer within 1 year period & 5.227 & PA21 \\
PA20 & Apply the relationship of management customer & 5.205 & \\
PA21 & Increase the PPIC performance & 5.279 & \\
PA22 & Increase the coordination and communication with the customer & 5.205 & \\
PA8 & Increase the quality of result quality of cattle fattening by the time of high & 16.416 & \\
& market & & \\
PA16 & Perform data and document back-up of the company periodically & 11.124 & \\
\hline & & & \\
\end{tabular}

Based on Table 4, there are 10 priority risk mitigation actions from 24 risk mitigation measures that have been formulated. When viewed from the relationships of the above ten priority risk mitigation actions with priority risk sources, all of these measures can cover all the priority risk sources. In addition, these ten priority risk mitigation actions can cover other risk mitigation actions.

\section{Managerial Implication}

Managerial implications that can be applied by PT. Catur Mitra Taruma in performing the company's supply chain risk management is performing routine and consistent maintenance planning, maximizing the provision of vitamin-containing feed for cattle endurance against various diseases, conducting intensive and periodic marketing research, performing performance evaluation and corrective action on a regular basis, improve coordination and communication system with person in-charge (PIC) delivery of cattle to customers, diversify quality of local cattle-based beef quality, increase import realization by increasing cage capacity, improve company PPIC performance, optimize productivity as the demand for meat cattle increase, and back up important corporate data and documents on a regular basis.

\section{CONCLUSIONS AND RECOMMENDATIONS}

\section{Conclusions}

The results of identification and assessment of risk events that have been done, there are 29 risk events that potentially appear at PT. Catur Mitra Taruma. The risk incidence consists of 9 risk events in the process plan, 12 risk events in the source process, 7 risk events in the making process, 4 risk events in the delivery process, and 1 risk event in the return process. The source 
process has the most risk compared to other processes because it has the longest process chain than any other process chain.

Identification of risk sources indicates that there are 45 possible risk sources at PT. Catur Mitra Taruma. Results of the evaluation and determination of priority risk sources indicate that there are 13 priority risk sources identified based on the ranking of order of risk priority index (ARP) from each risk source using Pareto Diagram analysis. The priority risk sources consist of the quota of cattle imports from the frequently changing government (A23), natural/environmental factors affecting the process of raising cattle (A7), and seasonal factors affecting the sale of cattle (A9). There is a damage to machinery/equipment related to business processes (A20), an increase in imported beef prices (A37), a damage to IT systems (A19), a lack of involvement and care of workers in supporting activities within the company (A44), a sudden demand from customer/RPH (A33), a fluctuation demand from customer/RPH (A28), natural/environmental factors affecting transportation (A42), a performance factor of machine related to operational process (A8), a non competing cattle selling price (A29), and an existence of interruption/accident during transportation process (A39).

Based on the results of risk management analysis conducted, there are 10 priority risk mitigation actions that can be applied in PT. Catur Mitra Taruma. The results of this analysis were found by calculating the effectiveness rate (TEk) and the effectiveness level of implementation (ETDk) of risk mitigation measures that have been formulated and determining priority risk mitigation actions.

\section{Recommendations}

Suggestion recommended in this research for PT. Catur Mitra Taruma in performing the company's supply chain risk management is performing routine and consistent maintenance planning, maximizing the provision of vitamin-containing feed for cattle endurance against various diseases, conducting intensive and periodic marketing research, performing performance evaluation and corrective action on a regular basis, improving coordination and communication system with the person in-charge (PIC) delivery of cattle to customers, diversifying the local cattle-based beef quality, increasing import realization by increasing cage capacity, improving company PPIC performance, optimize productivity as the demand for meat cattle increase, and backing up important corporate data and documents on a regular basis.

\section{REFERENCES}

Ahmad RZ. 2008. Pemanfaatan cendawan untuk meningkatkan produktivitas dan kesehatan ternak. Jurnal Litbang Pertanian 27(3): 1-9.

Aini H, Syamsun M, Setiawan A. 2015. Risiko rantai pasok kakao di Indonesia dengan metode analytic network process dan failure mode effect analysis terintegrasi. Jurnal Manajemen \& Agribisnis 11(3): 209-219.

Anggrahini D, Karningsih PD, Sulistiyono M. 2015. Managing quality risk in a frozen shrimp supply chain: a case study. Procedia Manufacturing 4:252-260.https://doi.org/10.1016/j. promfg.2015.11.039.

An-nisa NS, Rizal S, Gendut S. 2015. Strategi pengembangan asuransi ternak sapi. Jurnal Manajemen \& Agribisnis 12(1): 27-35. https:// doi.org/10.17358/JMA.12.1.27.

[BPS] Badan Pusat Statistik. 2016. Statistik Pertanian 2016. Jakarta: Badan Pusat Statistik.

Chen JK. 2007. Utility priority number evaluation for FMEA.Journal of failure analysis and Prevention 7(5): 321-328. https://doi.org/10.1007/s11668007-9060-2.

Chen J, Amrik SS, Daniel IP. 2013. Supply chain operational risk mitigation: a collaborative approach. International Journal of Production Research 51(7): 2186-2199. https://doi.org/10.1 080/00207543.2012.727490.

Dewi DS, Syairudin B, Nikmah EN. 2015. Risk management in new product development process for fashion industry: case study in hijab industry. Procedia Manufacturing 4: 383-391. https://doi.org/10.1016/j.promfg.2015.11.054.

Firdausi A, Susilawati T, Nasich M, Kuswati. 2012. Pertambahan bobot badan harian sapi brahman cross pada bobot badan dan frame size yang berbeda. Jurnal Ternak Tropika 13(1):48-62.

Geraldin LH, Pujawan, IN, Dewi DS. 2007. Manajemen risiko dan aksi mitigasi untuk menciptakan rantai pasok yang robust. Jurnal Teknologi dan Rekayasa Teknik Sipil (TORSI) 2007: 53-64.

Handayani DI. 2014. Risiko rantai pasok minuman 
sari apel dalam perspektif sistem traceability. TI UNDIP: Jurnal Teknik Industri 9(1): 57-68. https://doi.org/10.12777/jati.9.1.57-68.

Hartini S. 2012. Peran inovasi: pengembangan kualitas produk dan kinerja bisnis. Jurnal Manajemen dan Kewirausahaan 14(1): 83-90. https://doi. org/10.9744/jmk.14.1.83-90.

Pujawan IN, Geraldin LH. 2009. House of risk: a model for proactive supply chain risk management. Business Process Management Journal 15(6): 953-967. https://doi. org/10.1108/14637150911003801.
Pujiastuti L. 2015. Stok Sapi Feedlotter. https://finance. detik.com/berita-ekonomi-bisnis/d-2990618/ stok-sapi-feedloter-170000-ekor-di-akhir-juliini-data-rincinya [13 Januari 2017].

Risqiyah IA, Santoso I. 2017. Risiko rantai pasok agroindustri salak menggunakan fuzzy FMEA. Jurnal Manajemen \& Agribisnis 14(1):1-11. https://doi.org/10.17358/jma.14.1.1.

Ulfah M, Maarif MS, Sukardi, Sapta R. 2016. Analisis dan perbaikan manajemen risiko rantai pasok gula rafinasi dengan Pendekatan house of risk. Jurnal Teknologi Industri Pertanian 26(1): 87103. 